\title{
Implementation of Building Information Modeling (BIM) in Pakistan Construction Industry
}

\author{
Imtiaz Ali Bhatti \\ Faculty of Civil and Environmental \\ Engineering \\ Universiti Tun Hussein Onn Malaysia \\ Parit Raja, Johor, Malaysia \\ engrimtiaz290@gmail.com
}

\author{
Nabi Bux Bhatti \\ U.S.-Pakistan Centers for Advanced \\ Studies in Water \\ Mehran University of Engineering \& \\ Technology, Sindh, Pakistan \\ nabibuxbhatti76@gmail.com
}

\author{
Abd Halid Abdullah \\ Faculty of Civil and Environmental \\ Engineering \\ Universiti Tun Hussein Onn Malaysia \\ Parit Raja, Johor, Malaysia \\ abdhalid@uthm.edu.my \\ Samiullah Sohu \\ Faculty of Civil and Environmental \\ Engineering \\ Universiti Tun Hussein Onn Malaysia \\ Parit Raja, Johor, Malaysia \\ sohoosamiullah@gmail.com
}

\author{
Sasitharan Nagapan \\ Faculty of Civil and Environmental \\ Engineering \\ Universiti Tun Hussein Onn Malaysia \\ Parit Raja, Johor, Malaysia \\ sasitharan@uthm.edu.my \\ Ashfaque Ahmed Jhatial \\ Faculty of Civil and Environmental \\ Engineering \\ Universiti Tun Hussein Onn Malaysia \\ Parit Raja, Johor, Malaysia \\ aajhatial@hotmail.com
}

\begin{abstract}
This paper examines the implementation of building information modeling (BIM) in construction industry. Various initiatives and approaches are used in different countries to promote the BIM implementation in their construction industries. The real implementation and use of BIM remains a major concern of the construction industry. This study investigates the implantation of BIM globally, in developed countries and the percentage of implementation of BIM in constriction industry of Sindh, Pakistan. This research demonstrates 131 responses from BIM users regarding BIM implementation whose collaboration aspects produce the highest positive impact. The adopted methodology is an online questionnaire survey and literature review which was conducted to find out the implementation of BIM in construction industries of developed countries. This research reveals that BIM implementation is increasing continuously over the past few years. A Number of developed countries are emerging successful BIM implementation strategies, United States, United Kingdom, Germany, France are generally leading the way. However, according to our study findings, only $11 \%$ of industries have implemented BIM in Sindh, Pakistan.
\end{abstract}

Keywords-building information modeling; implementation; construction industry; developed \& developing countries

\section{INTRODUCTION}

Building information modeling (BIM) is a new innovative technology. The use of BIM technology is not limited only to the design of 3D models, but it can be used for detailed design and analysis, to create project documentation, to prepare estimates and to monitor the progress for ongoing project until completion [1]. Except that, BIM can be used for operation, maintenance and demolition of existing projects. BIM technology is used as a three-dimensional 3D model-based process which provides architecture, engineering and construction (AEC) professionals with more efficient planning, design, construction and management of buildings and infrastructure projects [2]. BIM can be viewed as a virtual process that encompasses all aspects, disciplines, and systems of a facility within a single virtual model, allowing all design team members (owners, architects, engineers, contractors, subcontractors, and suppliers) to collaborate more accurately and efficiently than using traditional processes [3, 4]. BIM also facilitates us to enhance decision making and implementation throughout the life cycle of a project [5-6]. Previously most of design decisions were taken by experts who were designing the project according to client specifications and requirements because the client himself or other technical people could not take decisions on their behalf. But in modern days, BIM technology has brought all stakeholders to one platform where they can contribute from the initial design process to the end of the project. The implementation of BIM is a problem for developed and developing countries, whereas in developed countries their government, technical organizations and institutions are performing great role to implement BIM technology and it has been found that they have succeeded to a certain level. The implementation of BIM is a chronic concern for developing countries like, Malaysia, Sri Lanka, India, Pakistan etc. This research is limited for Sindh, Pakistan. The primary objective of this study is to identify the percentage of BIM implementation in Pakistan construction industry.

BIM as an official term was used in 1992 and later on in a 2000 software called "Revit Software". After that the same software was sold to Autodesk and they brought many new changes in 2004. Currently that software is known as Autodesk Revit. BIM has brought revolutionary change in the field of building design to some high level of extent [2]. According to [7] BIM provides a platform to work with collaboration. In 
BIM, a single project can be subdivided into different phases because in a single project there is involvement of different experts of various fields depending upon the nature and type of project. They accumulate their work together into a single project. Therefore, different experts in various fields using BIM software don't have worry about the design process because integration and coordination will be dome by the system automatically. A wide research is ongoing to realize the issues for BIM implementation in construction industry [8-10] and to communicate the advantages of real BIM implementation to construction industry [11-12]. Authors in [13] have been tracking the evolution and implementation of BIM in global construction industry. They report that BIM implementation was $26 \%$ in 2007 and over doubled in less than a decade, reaching $57 \%$ in 2016 . BIM is widely used in United States, United Kingdom and Western Europe. Familiarity of BIM spread out among developed and developing countries and, after 2007, the ratio of BIM users increases. Increasing ratio of BIM usage is considerably higher in developed countries rather than in developing countries. In North America a survey was carried out regarding BIM implementation in construction industry. In 2008 it was recorded that only $28 \%$ of construction companies were using BIM, but when construction industry got familiar with the advantages of BIM, the escalation reached to $72 \%$ in 2012. Authors in [13] predicted that this will continue to escalate, with BIM market from 1.8 billion USD in 2012 to reach 6.5 billion USD by 2020 . Sudden increase in number of BIM projects is anticipated over the next 18 months transforming well beyond the achievement to date. Authors in [13] carried out a survey and collected responses of 727 contractors from developed and developing countries regarding BIM implementation in the top ten of the largest national construction markets in the world. United States, United Kingdom, Germany, Malaysia, France, Australia, Canada, India, Singapore, Sri Lanka and Middle East had been reviewed as described below.

\section{A. United States}

A significant number of construction companies in US believe that BIM has a potential to reduce the cost of the projects. This is the reason why $72 \%$ of companies are using it.

\section{B. United Kingdom}

According to [15] BIM implementation in UK had reached $54 \%$, whereas in 2015 it was $48 \%$. Since April 2016, the government has issued a strategy for construction companies, which aims to achieve $20 \%$ savings in procurement cost.

\section{Germany}

BIM implementation in Germany has reached up to $90 \%$ $\lceil 14\rceil$. Most of the construction companies and clients are aware about BIM technology so there is a demand for it.

\section{Malaysia}

Only $20 \%$ of the architectural firms are implementing BIM while $10 \%$ of surveying firms are using it $[11,16,17]$.

\section{E. France}

In 2014 the government of France decided to develop 500,000 houses in 2017 by using BIM for that project [18].
They digitized the building industry by investing 20 million euros. Today $65 \%$ of construction companies are using BIM aiming to achieve sustainability and reduced costs [18].

\section{F. Australia}

A research was carried out through a series of interviews with 25 construction companies from two major cities in the state of Queensland. They found that $51 \%$ of companies use BIM [19].

\section{G. Canada}

Canada has founded various organizations to adopt and implement BIM, like Canada BIM council, Institute for BIM in Canada and Building Smart Canada. This is the reason why the ratio of implementing BIM has reached $67 \%$ and still keeps on increasing.

\section{H. India}

BIM adoption in India is very low compared to other countries. According to research, it is found that only $22 \%$ construction companies are using BIM. In India BIM is also known as virtual design and construction (VCD) [20].

\section{Singapore}

BIM has transformed the construction industry. Singapore BIM implementation rate is rising rapidly [21].

\section{J. Middle East}

According to [22] BIM is implemented by $10 \%$ of construction companies on their projects.

\section{BENEFITS OF USING BIM}

Based on the survey responses and interviews conducted in previous studies, it is found that BIM has potential and must be deployed in construction industry. Most respondents have significantly reduced cost and time with the use of BIM [24], some professionals using BIM reported that it helps improve coordination among different stakeholders, such as architects, contractors, suppliers and other project team members. Publications, researches and policies have been developed to implement BIM. The governments of US, UK, Germany, Canada and other developed countries have made the implementation of BIM compulsory in their industries [24]. In UK and Canada there's a high level of BIM awareness because UK government has invested on their professionals to be trained in BIM technology, whereas a number of institutions launched by Canadian government are specialized to aware professionals about BIM, while European countries like Finland, Denmark, Norway and Sweden are known as BIM leaders [25].

\section{MethodOLOGY}

Based on the collected information, an online questionnaire was developed and distributed for collecting data regarding the practical implementation of BIM in construction industry of Sindh, Pakistan from targeted participants. The link to the questionnaire survey was sent to contracting companies, consultant and architectural firms and engineers. The firms' email addresses were obtained from their websites, whereas the engineers were contacted through social networks. The 
questionnaire was consisting of personal information and just only 11 questions regarded the BIM evaluation. The combined sample size of the study is summarized in Table I.

TABLE I. CONSTRUCTION CONTRIBUTOR

\begin{tabular}{|c|c|}
\hline Types of Contributors & Questionnaires distributed \\
\hline Contracting Companies & 50 \\
\hline Consultant \& Architecture & 50 \\
\hline Engineers (1-5 years' experience) & 100 \\
\hline
\end{tabular}

\section{SURVEY QUESTIONAIRE}

The questionnaire consisted of two sections, section A inquiring the demographics of the respondents while section $\mathrm{B}$ was related to BIM in construction industry of Pakistan. The survey questionnaire is depicted in the appendix.

\section{RESULTS AND DISCUSSION}

\section{A. Survey Analysis}

The questionnaire survey respondents were contracting companies, consultant and architectural firms and engineers. The response rate from contracting companies was $58 \%$, from consultant and architectural firms $62 \%$ and from engineers $71 \%$. All the companies were of medium size having 1-100 employees and all engineers had 3-5 years of experience. The survey analysis is shown in Table II.

TABLE II. SURVEY RESULTS

\begin{tabular}{|c|c|c|c|}
\hline \multicolumn{4}{|c|}{ Survey Analysis } \\
\hline Respondents & Sample Size & $\begin{array}{c}\text { Respond } \\
\text { Rate }\end{array}$ & $\begin{array}{c}\text { Respond } \\
\text { Percentage }\end{array}$ \\
\hline $\begin{array}{c}\text { Contracting } \\
\text { Companies }\end{array}$ & 50 & 29 & $58 \%$ \\
\hline $\begin{array}{c}\text { Consultant \& } \\
\text { Architectural Firms }\end{array}$ & 50 & 31 & $62 \%$ \\
\hline Engineers & 100 & 71 & $71 \%$ \\
\hline
\end{tabular}

\section{B. Response Analysis}

\section{1) Contracting Companies}

Questionnaires were distributed among 50 contracting companies and only 29 of them responded. When their responses were further analyzed, 4 companies were using Revit Architecture software which is a BIM application to generate only 3D geometrical models, 11 companies had known BIM but were not implementing it and 14 companies were unaware about BIM. This shows that only $8 \%$ of contracting companies were using a BIM application which is a very limited and initial stage of BIM, and only to generate 3D geometrical models.

\section{2) Consultant and Architectural Companies}

Questionnaires were distributed among 50 companies and only 31 companies responded. Only 7 companies were using a BIM application to generate 3D geometrical models for architectural and MEP services, their percentage being $14 \%$ which only shows that these firms are also using BIM to a very limited level. 24 companies were familiar to BIM but they were using other applications to generate 3D models.

\section{3) Engineers}

Questionnaires were distributed among 100 engineers and 71 of them responded. Only 11 engineers were familiar with BIM and their knowledge of BIM applications was focused only in $3 \mathrm{D}$ geometric model generation. The rest of the engineers were not familiar with BIM.

\section{CONCLUSION}

BIM has altered the way of designing, constructing and operating buildings. BIM utilization led to augmented profitability, reduced cost, reduced project duration and enhanced customer-client relationships. Implementation of BIM has progressed rapidly. In a global scale, in 2007 it was $26 \%$ and in 2016 it reached $57 \%$. BIM implementation is an enduring problem in developing countries. In Pakistan only $11 \%$ of related industry has implemented BIM and only to generate $3 \mathrm{D}$ models which is a very limited part of BIM.

\section{APPENDIX}

The survey questionnaire which was distributed among the respondents, section-wise follows.

Section A: Demographics

1. Name and address of company / organization

2. Type of your Organization

Consultant $\quad \square \quad$ Contractor

$$
\text { Client } \quad \square \quad \text { Other (please specify) }
$$

3. Type of building project undertaken by your company

$$
\begin{aligned}
& \text { Residential Building } \\
& \text { Non-Residential Building } \\
& \text { Others (please specify) }
\end{aligned}
$$

4. The size of projects you have involved in terms of contract amount:

$\square \quad 0-50$ million PKR

51-100 million PKR

101-500 million PKR

Above 500 million PKR

5. Level of your Academic Qualification

$\square \quad$ Diploma $\quad \square \quad$ Bachelors

$\square \quad$ Masters $\quad \square \quad$ Ph.D

6. Years of working Experience in Construction Industry

$\square \quad 0-5$ years $\quad \square \quad 6-10$ years

11-15 Years $\quad \square \quad 16-20$ Years

21-25 Years $\quad \square \quad$ More than 25 Years

7. Current Position in the Organization

$\square \quad$ Engineer $\quad \square \quad$ Construction Manager

$\begin{array}{lll}\text { Planner } & \square & \text { Project Manager } \\ \text { Quantity Surveyor } & \square \quad \text { Resident Engineer } \\ \text { Contracts Manager } & \square \quad \text { General Manager }\end{array}$

Section B: Implementation of BIM in Construction Industry of Pakistan

1. Are you aware of BIM and its benefits?

$\square \quad$ Yes $\quad \square \quad$ No

2. Is your company aware of BIM and its uses?

$\square \quad$ Yes $\square \quad$ No

3. Does your company use any BIM Software?

$\square \quad$ Yes $\quad \square \quad$ No

4. Which BIM software is used in your company/Organization if any?

$\square \quad$ Revit (Arch, Struct, MEP) $\quad \square \quad$ ArchiCAD

$\square \quad$ Vectorworks Architect $\quad \square \quad$ MicroStation

5. 5. Do you believe that industry is not yet clear enough of what BIM actually is?

$\square \quad$ Yes $\quad \square \quad$ No 


\section{REFERENCES}

[1] S. Frolov, A. Hovorun, M. Ostapenko, "Prospects for the innovative development of information technology in Ukraine during economic crisis”, Innovative Marketing, Vol. 13, No. 1, pp. 55-60, 2017

[2] A. T. Haron, A. J. Marshall-Ponting, G. F. Aouad, "Building information modelling in integrated practice", 2nd Construction Industry Research Achievement International Conference, Kuala Lumpur, Malaysia, November 3-5, 2009

[3] A. Bataw, On the integration of Building Information Modelling in undergraduate civil engineering programmes in the United Kingdom, $\mathrm{PhD}$ Thesis, University of Manchester, 2015

[4] I. Petri, S. Kubicki, Y. Rezgui, A. Guerriero, H. Li, “Optimizing Energy Efficiency in Operating Built Environment Assets through Building Information Modeling: A Case Study”, Energies, Vol. 10, No. 8, pp. 1167-1183, 2017

[5] M. Bilal, L. O. Oyedele, J. Qadir, K. Munir, O. O. Akinade, S. O. Ajayi, H. A. Alaka, H. A. Owolabi, "Analysis of critical features and evaluation of BIM software: towards a plug-in for construction waste minimization using big data", International Journal of Sustainable Building Technology and Urban Development, Vol. 6, No. 4, pp. 211-228, 2015

[6] M. Gerges, O. Ahiakwo, M. Jaeger, A. Asaad, "Building Information Modeling and Its Application in the State of Kuwait", International Journal of Civil, Environmental, Structural, Construction and Architectural Engineering, Vol. 10, No. 1, pp. 81-86, 2016

[7] S. B. Mohd, Building Information Modelling (BIM) Implementation Model for Construction Project Design Stage, MSc Thesis, Universiti Tun Hussein Onn Malaysia, 2015

[8] HM Government, Building Information Modelling. Industrial Strategy: Governement and Idustry in Partnership, Crown, 2012

[9] P. Smith, "BIM implementation - Global strategies", Procedia Engineering, Vol. 85, pp. 482-492, 2014

[10] H. Son, S. Lee, C. Kim, "What drives the adoption of building information modeling in design organizations? An empirical investigation of the antecedents affecting architects' behavioral intentions", Automation in Construction, Vol. 49, Part A, pp. 92-99, 2015

[11] M. Harris, E. Ismail, A. H. Hussain, "Business value of BIM in Malaysia's AEC industry: Preliminary findings", Malaysian Construction Research Journal, Vol. 16, No. 1, pp. 31-41, 2015

[12] S. Scheer, R. Mendes Jr., T. F. Campestrini, M. C. Garrido, "On-Site BIM Model Use to Integrate 4D/5D Activities and Construction Works: A Case Study on a Brazilian Low Income Housing Enterprise”, 2014 International Conference on Computing in Civil and Building Engineering, Orlando, USA, pp. 455-462, June 23-25, 2014

[13] McGraw Hill Construction, The business value of BIM for construction in major global markets, McGraw Hill, 2014

[14] W. Natephra, A. Motamedi, T. Fukuda, N. Yabuki, "Integrating building information modeling and virtual reality development engines for building indoor lighting design", Visualization in Engineering, Vol. 5, 2017

[15] NBS, National BIM Report, available at: https://www.thenbs.com /knowledge/national-bim-report-2016, 2016

[16] N. F. Azmi, C. S. Chai, L. W. Chin, "Building Information Modeling (BIM) in Architecture, Engineering and Construction (AEC) Industry: A Case Study in Malaysia", in: Proceedings of the 21st International Symposium on Advancement of Construction Management and Real Estate, pp. 401-412, Springer, 2018

[17] S. A. Abdullah, N. Sulaiman, A. A. Latiffi, D. Baldry, "Building Information Modeling (BIM) from the perspective of Facilities Management (FM) in Malaysia", International Real Estate Research Symposium, April 29-30, 2014

[18] R. Davies, F. Crespin-Mazet, A. Linne, C. Pardo, M. I. Havenvid, C. Harty, C. Ivory, R. Salle, "BIM in Europe: Innovation Networks in the Construction Sectors of Sweden, France and the UK", 31st Annual ARCOM Conference, Lincoln, UK, pp. 1135-1144, September 7-9, 2015

[19] K. Panuwatwanich, M. L. Wong, J. H. Doh, R. A. Stewart, T. J. McCarthy, "Integrating building information modelling (BIM) into
Engineering education: an exploratory study of industry perceptions using social network data", Australasian Association for Engineering Education Conference , pp. 1-9, 2013

[20] A. Sawhney, State of BIM Adoption and Outlook in India, RICS School of Built Environment, 2014

[21] T. Kaneta, S. Furusaka, A. Tamura, N. Deng, "Overview of BIM Implementation in Singapore and Japan", Journal of Civil Engineering and Architecture, Vol. 10, pp. 1305-1312, 2016

[22] Beale \& Company, BIM implantation in the UAE on the rise, Beale \& Company, 2017

[23] H. M. Hamada, A. Haron, Z. Zakiria, A. M. Humada, "Benefits and Barriers of BIM Adoption in the Iraqi Construction Firms", International Journal of Innovative Research in Advanced Engineering, Vol. 3, No. 8 , pp. 76-84, 2016

[24] B. Wang, End user Oriented BIM enabled Multi-functional Virtual Environment Supporting Building Emergency Planning and Evacuation, PhD Thesis, Cardiff University, 2014

[25] D. Bryde, M. Broquetas, J. M. Volm, "The project benefits of building information modelling (BIM)", International Journal of Project Management, Vol. 31, No. 7, pp. 971-980, 2013 